\title{
Effect of pre-supplementation with Pleurotus sajor-caju crude extracts on body weight and consequence responses of leukocytes and immune organs in fancy carp following inoculation with Aeromonas veronii
}

\author{
Sitthichon Rattanachan ${ }^{1}$, Sumrarn Bunnajirakul ${ }^{1}$ (D) and Darsaniya Punyadarsaniya ${ }^{2}$ (D)
}

1. Clinic for Aquatic Animals, Faculty of Veterinary Medicine, Mahanakorn University of Technology, Bangkok, Thailand;

2. Department of Microbiology, Faculty of Veterinary Medicine, Mahanakorn University of Technology, Bangkok, Thailand.

Corresponding author: Sitthichon Rattanachan, e-mail: rsitthic@mut.ac.th

Co-authors: SB: sumrarn@mut.ac.th, DP: darsaniy@mut.ac.th

Received: 29-01-2020, Accepted: 16-04-2020, Published online: 31-05-2020

doi: www.doi.org/10.14202/vetworld.2020.1010-1016 How to cite this article: Rattanachan S, Bunnajirakul S, Punyadarsaniya D (2020) Effect of pre-supplementation with Pleurotus sajor-caju crude extract on body weight and consequence response of leukocytes and immune organs in fancy carp following inoculation with Aeromonas veronii, Veterinary World, 13(5): 1010-1016.

\begin{abstract}
Aim: The present study aimed at highlighting the effects of oyster mushroom (Pleurotus sajor-caju), as a dietary supplement on growth performance, differential leukocytes population, and histological changes of melanomacrophage centers (MMCs) in spleen and kidney of fancy carp on bacterial infection.

Materials and Methods: A total of 60 fancy carp were allocated into four groups according to feed formulations including; (1) basal diet with $2 \%$ crude extract of P. sajor-caju, (2) basal diet with $2 \% \beta$-glucan, whereas Group 3 , and Group 4 were positive and negative control, which were fed only basal diet. Diets were provided for 30 days, thereafter, fish of Group 1 to Group 3 were intraperitoneally injected with Aeromonas veronii $\left(1.8 \times 10^{9} \mathrm{CFU}\right)$, whereas Group 4 was injected with normal saline. At day 7 post-bacterial inoculation, all fish were weighed, whole blood was collected for differential white blood cell count, and two visceral organs, posterior kidney and spleen, were collected from euthanized fish to observe histological changes, particularly MMCs.

Results: No significant differences in body weight were found $(p>0.05)$ at $1^{\text {st }}$ week of the experiment; however, fish body weight was significantly increased from week 2 to week 4 of the experiment. Increased monocyte number was found in carp fish fed with the $P$. sajor-caju or $\beta$-glucan supplemented diets compared to the control groups $(\mathrm{p}<0.05)$. The proliferation of monocyte in fish was consistent with increased number and size of MMCs in hemotopoietic organs, posterior kidney and spleen, especially in fancy carp fed with of P. sajor-caju crude extract and commercially available $\beta$-glucan before bacterial inoculation in fish.
\end{abstract}

Conclusion: These findings indicate that crude polysaccharide from P. sajor-caju can be potentially used as a feed additive that might promote innate immune function in fish.

Keywords: Aeromonas veronii, body weight, fancy carp (Cyprinus carpio), immunostimulant, Pleurotus sajor-caju.

\section{Introduction}

Immunostimulation in fish is induced by providing some substances to enhance the functional roles of innate immune response and to promote the endogenous defense systems. Therefore, the application of immunostimulants in fish farming might be very useful since it could offer protection against infection by aquatic pathogens with subsequent reduction of expenses related with the use of chemicals or medicines. As a result, sources of immunostimulating substances are nowadays extensively investigated. These kinds of materials can be produced synthetically or can be isolated from natural sources with different effectiveness. However, there are concerns about the

Copyright: Rattanachan, et al. Open Access. This article is distributed under the terms of the Creative Commons Attribution 4.0 International License (http://creativecommons.org/licenses/ by/4.0/), which permits unrestricted use, distribution, and reproduction in any medium, provided you give appropriate credit to the original author(s) and the source, provide a link to the Creative Commons license, and indicate if changes were made. The Creative Commons Public Domain Dedication waiver (http:// creativecommons.org/publicdomain/zero/1.0/) applies to the data made available in this article, unless otherwise stated. possible toxic effects of synthetic drugs and chemicals on humans and animals [1]. Furthermore, excessive chemicals or drugs use for the control of infectious diseases in aquaculture farms can also cause negative effects on the aquatic environment [2]. In contrast, the application of natural immune promoting substances might be less toxic, less expensive, without inducing accumulation in animals and environment [3], thus use of natural immunostimulating dietary additives in fish farm can be beneficial for sustainable aquaculture.

Mushrooms is a kind of fungi that have been considered to be a source of food for human and animals since mushroom contains adequate levels of total carbohydrates, dietary fiber, protein, nitrogen, and ash [4]. In addition to their nutrients, mushrooms have been used as a traditional medicine due to their biological components, particularly immunomodulators such as terpenoids, lectins, fungal immunomodulatory proteins, and polysaccharides, which can trigger inflammatory processes and stimulate the activity of white blood cells that are involved in protecting organism against pathogens [5]. Some polysaccharides, such as 
beta glucan ( $\beta$-glucan), possess beneficial properties including anti-inflammatory, antitumor, antimicrobial, antidiabetic, and immunostimulative activities [6].

To evaluate the effectiveness of mushroom as an alternative source of nutrient promoting of health benefits in fish; therefore, this experiment aimed to highlight the effects of edible oyster mushroom (Pleurotus sajor-caju), as a dietary supplement on growth performance, differential leukocyte profile, and histological changes of some visceral organs in fancy carp (Cyprinus carpio).

\section{Materials and Methods}

Ethical approval

This study was approved by the Ethics Committee of the Animal Care and use Committee of Mahanakorn University of Technology (Approval no. ACUC-MUT-2018/002).

\section{Mushroom preparation and extraction}

Freshly purchased oyster mushrooms, $P$. sajorcaju, were cleaned by rinsing with tap water and minced into small pieces. Then, all minced mushrooms were air-dried in a hot air oven at a temperature at $40^{\circ} \mathrm{C}$ for 3 days to ensure a complete drying [6]. To obtain a crude extract of oyster mushroom, a hot water extraction method $[7,8]$ partially modified was performed. Dried minced mushrooms were ground into a fine powder and subsequently combined with distilled water at a ratio of 1:20 and later boiled in a water bath at the temperature at $70^{\circ} \mathrm{C}$ for $5 \mathrm{~h}$. The mixture was then filtrated through a sterile nylon sieve 2 times to remove dirt and the supernatant was collected and sent to central instrument facilities, Faculty of Science, Mahidol University. It was then lyophilized to obtain freeze-dried crude extract of oyster mushroom. This lyophilized crude extract was then stored at $-20^{\circ} \mathrm{C}$ until further use.

Measurement of total carbohydrate and total protein

Total carbohydrate levels of crude oyster mushroom extract were measured using the total Carbohydrate Quantification Assay Kit (Abcam, United Kingdom), according to the kit instructions. Total protein content of crude extract was also determined by Bradford assay $[9,10]$ using Bradford reagent (AppliChem, Darmstadt, Germany), according to manufacturer's instructions with bovine serum albumin for a standard protein.

\section{Fish and experimental design}

A total 60 healthy fancy carps (C. carpio) with average body weight of $35 \mathrm{~g}$ and total length of body is $10 \mathrm{~cm}$, which were purchased from local fish aquarium, were housed in glass tanks with aeration supplied for 7 days of the acclimatization. During this period, all fish were fed by commercial standard diet by $3 \%$ of body weight/fish, 2-times a day. After a period of acclimatization, all fish were divided into four major groups regarding to each experimental condition as following, (1) basal diet with $2 \%$ crude mushroom extract, (2) basal diet with $2 \% \beta$-glucan, whereas Group 3 and Group 4 were positive and negative control, which were fed only basal diet, respectively, each major group was replicated as three small groups comprised five fish per group (total $\mathrm{n}=15 \mathrm{fish} /$ condition). During 30 days of the experiment, water parameters include temperature, dissolved oxygen, chlorine, $\mathrm{pH}$, ammonia, and alkalinity were weekly detected (data not shown).

\section{Preparation of supplemented diets and feeding regime}

The crude mushroom extract supplemented diet was prepared by incorporating $2 \%$ crude extract coated by vegetable oil into the diet [11] and was airdried before its provision to the fish. The $\beta$-glucan supplemented diet was also prepared as previously described [11]. All experimental groups were fed twice per day continuously for 30 days.

\section{Bacterial preparation and experimental inoculation}

Aeromonas veronii biovar sobria, which was isolated from naturally infected fish in a farm, was identified by the Department of Medical Sciences, Ministry of Public Health, Thailand. Thereafter, bacteria were maintained in MacConkey agar (Oxoid ${ }^{\mathrm{TM}}$,United Kingdom). A single colony of bacteria on the agar was then grown in Luria Bertani (LB) broth with $1 \% \mathrm{NaCl}$ and kept at $37^{\circ} \mathrm{C}$ for $18 \mathrm{~h}$. The amount of bacterial was quantitated as colony-forming unit per $\mathrm{mL}(\mathrm{CFU} / \mathrm{mL})$ by agar plate dilution method. A stock of suspended bacteria was subsequently diluted with LB broth until the amount of bacteria were at approximately $1.8 \times 10^{9}$ $\mathrm{CFU} / \mathrm{mL}$ [12] and later washed 3 times with $0.9 \%$ sterile normal saline solution and finally suspended in $0.3 \mathrm{~mL}$ of normal saline before inoculation.

At day 30 of the experiment, experimental inoculation of fish by bacteria was carried out; all fish were sedated using clove oil as an anesthetic agent that was dissolved in $95 \%$ ethanol with a ratio of $1: 10$. Anesthesia of all fish was performed by short immersion in an anesthetic tank. All fish of Group 1 to Group 3 were then inoculated intraperitoneally with $0.3 \mathrm{~mL}$ of suspended bacteria, whereas fish from Group 4 were inoculated only normal saline solution. After inoculation, all fish were observed for 7 days to record their behavior and clinical signs due to the infection.

\section{Sample collection}

During the feeding period, fish from each group were weekly weighed to measure body weight $(\mathrm{g})$. Seven days after the experimental inoculation with bacteria, the blood samples were also collected from all experimental fish through the caudal blood vessel, and fish were then euthanized through the immersion for $10 \mathrm{~min}$ in water containing buffered tricaine methanesulfonate (MS-222, Merck, Germany), with a $\mathrm{pH}$ between 7.0 and 7.5. The blood samples from fish were smeared on a glass slide and stained using DiffQuick staining set and later evaluated microscopically 
by differential white blood cell count for the number of neutrophils, monocyte, and lymphocyte. Then, all euthanized fish were dissected abdominally to remove spleen and kidney and subsequently preserved into $10 \%$ buffered formalin. These organs were then sent to MUT Veterinary Diagnostic Center for the examination of histological changes using a light microscope. The paraffinized tissue was embedded, sectioned, and stained by hematoxylin and eosin before the analysis.

\section{Statistical analysis}

Body weight of fish is presented as group average body weight (g) \pm standard deviation (SD). Differential white blood cell count, number of neutrophils, monocyte, and lymphocyte are presented as min, max, and average $(\overline{\mathrm{x}}) \pm \mathrm{SD}$. The above variables were evaluated by one-way analysis of variance using IBM SPSS Statistics version 23 (IBM Corp, Armonk, New York), Subscription Trial activated December 18, 2018. The probability level below 0.05 was considered significantly different.

\section{Results and Discussion}

\section{$P$. sajor-caju and its crude extract}

Our result demonstrated that crude extract of P. sajor-caju (oyster mushroom) can be prepared using the hot water extraction method as previously described [7] with slight modifications. In this study, $100 \mathrm{mg}$ of crude mushroom extract contained $14.64 \mathrm{mg}$ of total carbohydrate and $0.084 \mathrm{mg}$ of total protein, respectively. This fact indicates that is feasible to isolate nutrients from oyster mushroom crude extract by the hot water extraction method. In our experiment, we did not detect any kind of nutrients that is associated with immune enhancement in mammals, particularly $\beta$-glucan for instance, however, as indicated by the previous experiment [7], the extraction of ground Pleurotus pulmonarius by this method can provide a high yield of crude protein (23.14 g per $100 \mathrm{~g}$ of mushroom dried weight) and crude carbohydrate $(48.24 \mathrm{~g} / 100 \mathrm{~g}$ of mushroom dried weight) and also $\beta$-glucan $(20.05 \mathrm{~g})$. The yield of crude carbohydrate and crude protein from oyster mushroom, in our study, was quite low compared to other studies using water as a solvent and various boiling temperature with additional enzyme for extraction $[7,8,13]$; however, a yield of crude polysaccharide obtained from mushroom depends on sample nature, extraction temperature, cooking pressure, $\mathrm{pH}$, ionic strength of the solvent, and fineness of ground dried mushroom particle [14]. The analysis of crude mushroom extract is illustrated in Table-1 [7,11].

\section{Effect of $\boldsymbol{P}$. sajor-caju crude extracts dietary supple- mentation on fish body weight}

In our experiment, fish mean body weight from each experimental group was weekly recorded, as shown in Table-2. At week 1 of the experiment, no significant differences in body weight among the four groups were observed. The mean body weight for negative controls, positive controls, fish supplemented with $P$. sajor-caju mushroom crude extract, and fish supplemented with $\beta$-glucan was $35.29 \pm 0.76 \mathrm{~g}$, $35.29 \pm 0.76 \mathrm{~g}, 35.29 \pm 0.72 \mathrm{~g}$, and $35.57 \pm 1.43 \mathrm{~g}$, respectively. At week 2, the highest mean body weight was observed in fish fed the $\beta$-glucan supplemented diet $(39.00 \pm 0.00 \mathrm{~g})(\mathrm{p}<0.05)$, whereas no significant differences in the body weight among three other groups were found (37.00 \pm 0.00 vs. $37.29 \pm 0.71$ vs. $37.29 \pm 0.72 \mathrm{~g}$ for negative control, and positive control) and fish fed the mushroom crude extract supplemented diet, respectively $(\mathrm{p}>0.05)$. At week 3 , the highest to lowest mean body weight was: Positive controls $(39.71 \pm 1.89 \mathrm{~g})$, fish fed the mushroom crude extract supplemented diet $(39.50 \pm 1.25 \mathrm{~g})$, fish fed the $\beta$-glucan supplemented diet $(39.00 \pm 0.00 \mathrm{~g})$, and negative controls $(37.00 \pm 0.00 \mathrm{~g})$. The same order was also observed in week 4 of experiment including; $44.00 \pm 0.01 \mathrm{~g}, 42.50 \pm 0.01 \mathrm{~g}, 39.00 \pm 0.01 \mathrm{~g}$, and $37.00 \pm 0.06 \mathrm{~g}$, respectively $(\mathrm{p}<0.05$; Table-2). Interestingly, there was a slight effect of $\beta$-glucan on the body weight of fish, since the highest fish body

Table-1: P. sajor-caju, proximate parameters, and extraction condition.

\begin{tabular}{|c|c|c|c|}
\hline Mushroom & P. sajor-caju ${ }^{1}$ & P. sajor-caju² & P. pulmonarius ${ }^{3}$ \\
\hline Wet weight (g) & 150 & 2000 & ND \\
\hline Dry weight (g) & 31 & 222 & 100 \\
\hline Boiling water temperature $\left({ }^{\circ} \mathrm{C}\right)$ & 70 & 100 & ND \\
\hline Boiling time $(\mathrm{h})$ & 5 & ND & 5 \\
\hline Total protein & $0.084 \mathrm{mg} / 100 \mathrm{mg}$ of $\mathrm{CE}$ & ND & $23.14 \mathrm{mg}$ \\
\hline Total carbohydrate & $14.64 \mathrm{mg} / 100 \mathrm{mg}$ of CE & $11.4 \mathrm{~g}$ & $48.24 \mathrm{~g}$ \\
\hline
\end{tabular}

${ }^{1}$ Proximate data collected in this study, ${ }^{2}$ Data obtained from Dobšíková et al. [11] and ${ }^{3}$ Data obtained from Ahmed et al. [7]. $\mathrm{CE}=$ Crude extract, $\mathrm{ND}=$ Not described, $P$. sajor-caju=Pleurotus sajor-caju, $P$. pulmonarius=Pleurotus pulmonarius

Table-2: Mean body weight $(\mathrm{g})$ of carps per week.

\begin{tabular}{lccccc}
\hline Groups & Negative control & Positive control & Treatment 1 (mushroom) & Treatment 2 ( $\boldsymbol{\beta}$-glucan) & Significance* \\
\hline Week 1 & $35.29 \pm 0.76 \mathrm{~g}^{\mathrm{a}}$ & $35.29 \pm 0.76 \mathrm{~g}^{\mathrm{a}}$ & $35.29 \pm 0.72 \mathrm{~g}^{\mathrm{a}}$ & $35.57 \pm 1.43 \mathrm{~g}^{\mathrm{a}}$ & 0.933 \\
Week 2 & $37.00 \pm 0.00 \mathrm{~g}^{\mathrm{X}}$ & $37.29 \pm 0.71 \mathrm{~g}^{\mathrm{X}}$ & $37.29 \pm 0.72 \mathrm{~g}^{\mathrm{X}}$ & $39.00 \pm 0.00 \mathrm{~g}^{\mathrm{Y}}$ & 0.000 \\
Week 3 & $37.00 \pm 0.00 \mathrm{~g}^{\mathrm{A}}$ & $39.71 \pm 1.89 \mathrm{~g}^{\mathrm{B}}$ & $39.50 \pm 1.25 \mathrm{~g}^{\mathrm{B}}$ & $39.00 \pm 0.00 \mathrm{~g}^{\mathrm{B}}$ & 0.001 \\
Week 4 & $37.00 \pm 0.06 \mathrm{~g}^{\mathrm{I}}$ & $44.00 \pm 0.01 \mathrm{~g}^{\text {II }}$ & $42.50 \pm 0.01 \mathrm{~g}^{\mathrm{III}}$ & $39.00 \pm 0.01 \mathrm{~g}^{\mathrm{IV}}$ & 0.000 \\
\hline
\end{tabular}

*One-way ANOVA/different letters indicate significant differences $(p<0.05)$ (Tukey's HSD) at the same time period 
weight was found in positive controls, which was fed only the basal diet. This result was consistent with other researches [15-17] and might be attributed to the lack of the digestive enzyme called $\beta$-glucanase, which is responsible for the digestion of $\beta$-glucan [18]. As compared to fish fed the P. sajor-caju crude extract supplemented diets, mean body weight of fish was higher to fish fed by supplemented feed with $\beta$-glucan but slightly lower than fish of positive control group, this might imply that fish can utilize heated water-soluble nutrients of $P$. sajor-caju since the crude extract we used in this experiment contains both crude polysaccharide (14.64 mg/100 mg of crude extract) and crude protein $(0.084 \mathrm{mg} / 100 \mathrm{mg}$ of crude extract) crude extract). Several factors can affect fish body gain such as source and type of carbohydrate, type of digestive enzyme, and fish species especially herbivorous or carnivorous [19]. In our experiment, crude extract of $P$. sajor-caju was used without isolation of $\beta$-glucan and removal of starch carbohydrate and protein, this implies that cyprinid fish can utilize low molecular carbohydrate components and also other nutrients from water-soluble crude mushroom extract by amylase enzyme [19]. In addition to digestion of crude extract derived from mushroom in fish, indigenous components of mushroom polysaccharides such as chitin, hemicelluloses, $\alpha$ - and $\beta$-glucan, mannans, xylans, and galactose are potential source of prebiotics [20], which can utilize by gut microflora that indirectly provide the host for energy, metabolic substrates, and essential micronutrients [21].

Effect of $\boldsymbol{P}$. sajor-caju crude extracts dietary supplementation on fish differential leukocytes profile after the experimental infection with Aeromonas veronii

Health benefits effect of crude $P$. sajor-caju supplement in fancy carps on experimental infection with $A$. veronii bv. sobria at the $7^{\text {th }}$ day after inoculation was determined by manual differential leukocytes count through blood smear. In our study, no fish mortality was observed during experimental infection and the result of differential count (Table-3) shown that the population of neutrophils in negative controls (31.70 \pm 4.28 cells, $31.92 \%)$ and positive controls

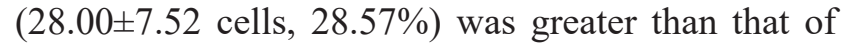
the groups dietary supplemented either with mushroom $(10.30 \pm 2.31$ cells, $10.29 \%)$ or with $\beta$-glucan $(7.58 \pm 1.49$ cells, $7.54 \%)(\mathrm{p}<0.05)$. This finding might be related to individual health status and biological responsiveness to environmental parameters [22]; however, increased average number of neutrophils was found especially in fish of negative control group, which was fed by only standard diet and not inoculated by bacteria, might be due to individually stress response to surrounding environment [23]. In addition to environmental stress, there are some reasons that the number of neutrophils population was fluctuated as observed on the $7^{\text {th }}$ day after inoculation. Havixbeck and Barreda [24] indicated that high number of neutrophils in blood circulation are from $6 \mathrm{~h}$ to $24 \mathrm{~h}$ for the acute response to bacterial infection and undergo apoptosis once pathogen is eliminated and later modulate the function of macrophage to remove of apoptotic cells [25]. Furthermore, CharlieSilva et al. [26] showed that the number of circulating neutrophils was decreased in tilapia infected with Aeromonas hydrophila in association with increased granulocyte accumulation in the inflammatory site. However, a high number of circulating neutrophils is possible in case of delayed apoptosis of neutrophils or impaired clearance of neutrophils at infection site and contributes to the prolong secretion of pro-inflammatory mediators such as granulocyte macrophage colony-stimulating factor, interleukin-8, or bacterial components [27]. For the population of lymphocyte, higher number of cells was also found in fish of positive control group (56.87 \pm 7.26 cells, $58.03 \%)$ and negative control group (53.37 \pm 3.16 cells, 53.74\%) compared to fish supplemented with mushroom (39.68 \pm 5.11 cells, $39.56 \%)$ and $\beta$-glucan $(35.83 \pm 2.83$ cells, $35.65 \%)(\mathrm{p}<0.05)$, this evidence

Table-3: Number of differential white blood cell count.

\begin{tabular}{|c|c|c|c|c|c|c|c|}
\hline \multirow{2}{*}{$\begin{array}{l}\text { Observed white } \\
\text { blood cell }\end{array}$} & \multirow[t]{2}{*}{ Group } & \multirow{2}{*}{$\begin{array}{c}\text { Number of animals } \\
\text { per group }\end{array}$} & \multicolumn{4}{|c|}{ Number of differential white blood cell } & \multirow[t]{2}{*}{ Significance* } \\
\hline & & & Min. & Max. & Mean \pm SD & $\%$ & \\
\hline \multirow[t]{4}{*}{ Neutrophils } & 1 & 15 & 20 & 43 & $31.70 \pm 4.28^{A}$ & 31.92 & 0.000 \\
\hline & 2 & 15 & 7 & 47 & $28.00 \pm 7.52^{\mathrm{A}}$ & 28.57 & \\
\hline & 3 & 14 & 6 & 19 & $10.30 \pm 2.31^{\mathrm{B}}$ & 10.29 & \\
\hline & 4 & 12 & 3 & 11 & $7.58 \pm 1.49^{\mathrm{B}}$ & 7.54 & \\
\hline \multirow[t]{4}{*}{ Lymphocyte } & 1 & 15 & 41 & 63 & $53.37 \pm 3.16^{c}$ & 53.74 & 0.000 \\
\hline & 2 & 15 & 29 & 76 & $56.87 \pm 7.26^{c}$ & 58.03 & \\
\hline & 3 & 14 & 21 & 55 & $39.68 \pm 5.11^{\mathrm{D}}$ & 39.56 & \\
\hline & 4 & 12 & 21 & 42 & $35.83 \pm 2.83^{\circ}$ & 35.65 & \\
\hline \multirow[t]{4}{*}{ Monocyte } & 1 & 15 & 3 & 35 & $14.23 \pm 3.67^{E}$ & 14.33 & 0.000 \\
\hline & 2 & 15 & 21 & 55 & $13.13 \pm 4.84^{\mathrm{E}}$ & 13.40 & \\
\hline & 3 & 14 & 50 & 70 & $50.32 \pm 5.51^{F}$ & 50.17 & \\
\hline & 4 & 12 & 50 & 74 & $57.04 \pm 2.72^{G}$ & 56.76 & \\
\hline
\end{tabular}

Group 1 (negative control), 2 (positive control), 3 (supplemented by Pleurotus sajor-caju), and 4 (supplemented by $\beta$-glucan)/* one-way ANOVA/different letters indicate significant differences $(p<0.05)$ (Tukey's HSD) at the same time period 
is possible because of partial death of fish was found during housing before starting inoculation with bacteria. Nevertheless, number of lymphocyte observed among four groups of experiment seem to be usual since most studies have indicated that lymphocyte in common carp is the major population of white blood cell, which commonly found approximately $80 \%$ of leukocyte population [28]. For the number of monocytes, it was found to be higher in carp fish group both fed by $P$. sajor-caju $(50.32 \pm 5.51$ cells, $50.17 \%)$ and fish group fed by $\beta$-glucan $(57.04 \pm 2.72$ cells, $56.76 \%$ ) compared to those in negative control group (14.23 \pm 3.67 cells, $14.33 \%)$ and positive control group $(13.13 \pm 4.84$ cells, $13.40 \%)(\mathrm{p}<0.05)$; however, it is interesting that no significant difference in the number of monocyte was noticed between fish supplemented with crude $P$. sajor-caju extract and by $\beta$-glucan ( $\mathrm{p}>0.05$ ). This implies that $2 \%$ crude extract of $P$. sajor-caju can improve some of innate immune response in carp fish, and this finding was similar with the previous studies; for instance, Safari and Sarkheil [29] found that $1.5-2 \%$ dietary administration of Pleurotus eryngii induced higher number of white blood cells, particularly, monocyte, and activities of immunoglobulin, lysozyme, and complement at 63 days of the experiment. In addition, Minato et al. [30] demonstrated that polysaccharide of eatable mushroom, Pleurotus citrinopileatus, can modulate the differentiation of monocyte to macrophage. Interestingly, Minato et al. [30] proved that the competitive inhibition of dectin-1 and toll-like receptor-2 (TLR-2) receptors for $\beta$-glucan and polysaccharide on monocyte can affect the differentiation from monocyte to macrophage. In addition, Garcia-Valtanen et al. [31] showed that the supplementation of $\beta$-glucan during in vitro culture of monocytes from murine and human correlated to the increased viability and lifespan of these cells and influenced the differentiation from monocytes to macrophages at day 5 of the experiment compared to monocytes without $\beta$-glucan. These evidences suggest that crude polysaccharide from Pleurotus spp. has beneficial effects on immune system in humans and animals.

\section{Histological changes of kidney and spleen in fancy carp after the experimental infection with the A. veronii}

Kidney and spleen tissue sections were collected from fancy carp to compare the histological changes among the four experimental groups. The result revealed proliferation of melanomacrophage centers (MMCs, Figures-1 and 2), which are focal accumulations of macrophages that contain pigments, such as hemosiderin, lipofuscin, ceroid, and melanin in hematopoietic tissue of organs such as posterior kidney and spleen [32]. Alteration in amount and size of MMCs was obviously observed in fish fed the mushroom crude extract supplemented diet (Figure-1e and 1f, Figure-2e and $2 \mathrm{f}$ ) and this finding was similar to that of fish fed with $\beta$-glucan supplemented diets (Figure-1g
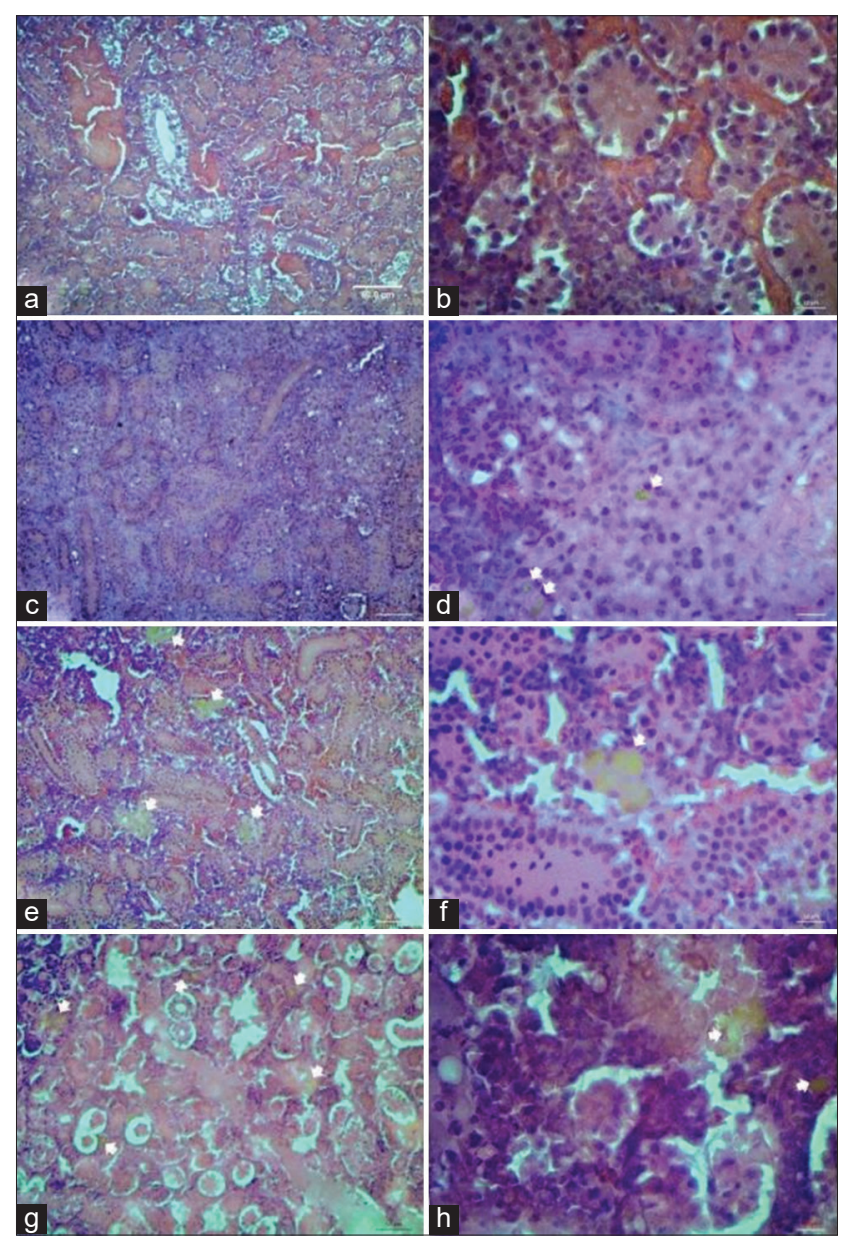

Figure-1: Histology of the posterior kidney (a, c, e, g, 100x power micrograph, b, d, f, h, 400x power micrograph) in fancy carp fish with four different feed supplements; negative control ( $a$ and $b)$, positive control ( $c$ and $d)$, fed with crude Pleurotus sajor-caju (e and $\mathrm{f}$ ), fed with $\beta$-glucan ( $g$ and $\mathrm{h}$ ). White arrows indicate melanomacrophage centers. Hematoxylin and Eosin staining.

and $1 \mathrm{~h}$, Figure- $2 \mathrm{~g}$ and $2 \mathrm{~h}$ ), whereas a lower number of smaller MMCs was found in fish of positive control group (Figure-1c and 1d, Figure-2c and 2d), which was not fed by any supplement. However, no proliferation of MMCs was found in fish of negative control group (Figure-1a and 1b, Figure-2a and $2 \mathrm{~b}$ ). This finding indicates that feed supplement using crude polysaccharide from $P$. sajor-caju and $\beta$-glucan might activate MMCs. This is quite similar to the results of a previous experiment [33] that accessed the effectiveness of microalgae Navicula sp. orally administration on immune response in Pacific red snapper. Melanomacrophage was predominantly observed in the submucosa of intestine with the higher serum immunoglobulin $\mathrm{M}$ and this evidence could be possibly attributed not only to the high content of $\beta$-glucan and cell wall polysaccharide [34] but also to the activation of MMCs was noticed in fish injected with infectious agent or non-infectious agent to trap and scavenge foreign bodies [35]. In addition, transmembrane protein receptor called dectin-1, which found in monocyte and macrophage, was a specific receptor for $\beta-1,3$-glucan, and might associate with TLR-2 on 


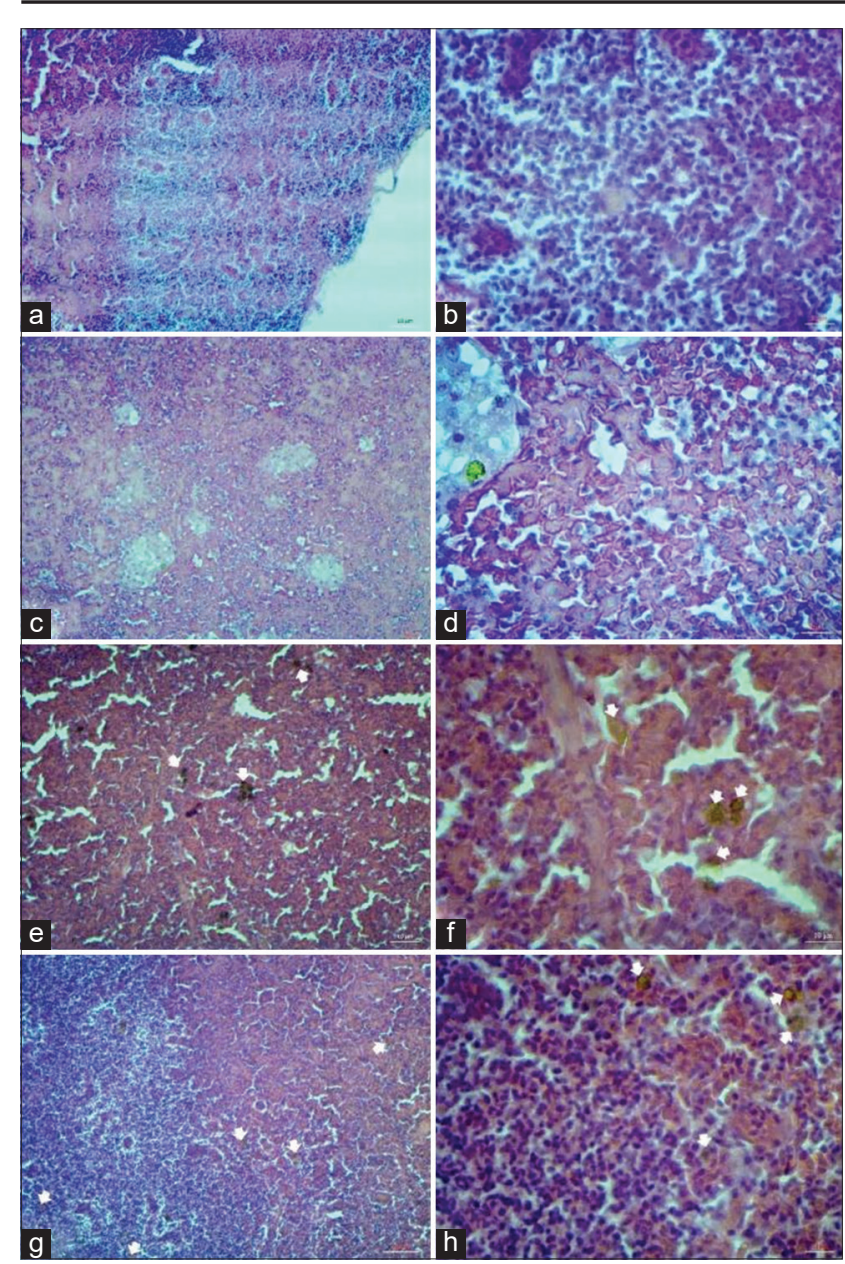

Figure-2: Histology of the spleen (a, c, e, g, 100x power micrograph, b, d, f, h, 400× power micrograph) in fancy carp fish with four different feed supplements; negative control ( $a$ and $b$ ), positive control ( $c$ and $d$ ), fed with crude Pleurotus sajor-caju (e and f), fed with $\beta$-glucan ( $g$ and $\mathrm{h}$ ). White arrows indicate melanomacrophage centers. Hematoxylin and Eosin staining.

macrophage for its activation in the presence of invading bacteria [36].

\section{Conclusion}

Overall findings demonstrate that water soluble extract of $P$. sajor-caju can be prepared by boiling in water, and its main ingredient is the crude polysaccharide. Supplement of P. sajor-caju crude extract in feed might be associated with improved weight gain in fish and increase of blood leukocytes, particularly monocyte, after the experimental infection with $A$. veronii. Proliferation of monocyte in fish was consistent with increasing number and size of MMCs in hemotopoietic organs, posterior kidney and spleen, especially in fancy carp fed with of P. sajor-caju crude extract and commercially available $\beta$-glucan before bacterial inoculation in fish. These evidences imply that crude polysaccharide from $P$. sajor-caju contribute to upregulation of innate immune function in animal. However, further investigations such as isolation and characterization of active ingredient that can be beneficial to immune system in animal, for example, glucans, for instance. In addition, initiation of phagocytic activity for monocyte and macrophage induced by the addition of crude polysaccharide isolated from P. sajor-caju should be further elucidated. Furthermore, cellular interactions of crude polysaccharide from mushroom and receptors on phagocytes and patterns of cytokines regulations of innate cells in response to invading pathogens are needed to clarify.

\section{Authors' Contributions}

SR was responsible for creating the research concept, conducting research, data collection and analysis, and drafting of the article. SB advised the experimental design and was also responsible for histological analysis of spleen, liver, and posterior kidney tissue samples. DP advised the experimental design and checking all figures of the article. All authors read and approved the final manuscript.

\section{Acknowledgments}

The authors are thankful for the financial support from the Research and Innovation promotion office, Mahanakorn University of Technology, Thailand (Grant number; 60-VET-DVM-4.1/019). Also, we are deeply grateful to the Faculty of Veterinary Medicine, Mahanakorn University, Thailand, for providing instruments during the experiment.

\section{Competing Interests}

The authors declare that they have no competing interests.

\section{Publisher's Note}

Veterinary World remains neutral with regard to jurisdictional claims in published institutional affiliation.

\section{References}

1. Paulozzi, L.J. (2012) Prescription drug overdoses: A review. J. Safety Res., 43(4): 283-289.

2. Kennedy, D., Cannavan, A. and Mccracken, R.J. (2000) Regulatory problems caused by contamination, a frequently overlooked cause of veterinary drug residues. $J$. Chromatogr. A., 882(1-2): 37-52.

3. Rastogi, T., Leder, C. and Kümmerer, K. (2015) Re-designing of existing pharmaceuticals for environmental biodegradability: A tiered approach with $\beta$-blocker propranolol as an example. Environ. Sci. Technol., 49(19): 11756-11763.

4. Mattila, P., Salo-Väänänen, P., Könkö, K., Aro, H. and Jalava, T. (2002) Basic composition and amino acid contents of mushrooms cultivated in Finland. J. Agric. Food. Chem., 50(22): 6419-6422.

5. El Enshasy, H.A. and Hatti-Kaul, R. (2013) Mushroom immunomodulators: Unique molecules with unlimited applications. Trends. Biotechnol., 31(12): 668-677.

6. Chong, V., Al-Azad, S. and Shapawi, R. (2016) Comparison of two edible mushroom extract as aquaculture feed additive to enhance immune response of Asian Seabass. Trans. Sci. Technol., 3(2-2): 427-432.

7. Ahmed, M., Abdullah, N., Shuib, A.S. and Razak, S.A. (2017) Influence of raw polysaccharide extract from mushroom stalk waste on growth and $\mathrm{pH}$ perturbation inducedstress in Nile tilapia, Oreochromis niloticus. Aquaculture, 468(1): 60-70.

8. Hu, H., Zhang, Z., Lei, Z., Yang, Y. and Sugiura, N. (2009) 
Comparative study of antioxidant activity and antiproliferative effect of hot water and ethanol extracts from the mushroom Inonotus obliquus. J. Biosci. Bioeng., 107(1): 42-48.

9. Bradford, M.M. (1976) A rapid and sensitive method for the quantitation of microgram quantities of protein utilizing the principle of protein-dye binding. Anal. Biochem., 72(1-2): 248-254.

10. Thetsrimuang, C., Khammuang, S. and Sarnthima, R. (2011) Antioxidant activity of crude polysaccharides from edible fresh and dry mushroom fruiting bodies of Lentinus sp. strain RJ-2. Int. J. Pharmacol., 7(1): 58-65.

11. Dobšíková, R., Blahová, J., Mikulíková, I., Modrá, H., Prášková, E., Svobodová, Z., Škorič, M., Jarkovský, J. and Siwicki, A.K. (2013) The effect of oyster mushroom $\beta-1.3 / 1.6-\mathrm{D}-$ glucan and oxytetracycline antibiotic on biometrical, haematological, biochemical, and immunological indices, and histopathological changes in common carp (Cyprinus carpio L.). Fish Shellfish Immunol., 35(6): 1813-1823.

12. Dong, H.T., Techatanakitarnan, C., Jindakittikul, P., Thaiprayoon, A., Taengphu, S., Charoensapsri, W., Khunrae, P., Rattanarojpong, T. and Senapin, S. (2017) Aeromonas jandaei and Aeromonas veronii caused disease and mortality in Nile tilapia, Oreochromis niloticus (L.). $J$. Fish Dis., 40(10): 1395-1403.

13. Carbonero, E.R., Ruthes, A.C., Freitas, C.S., Utrilla, P., Gálvez, J., da Silva, E.V., Sassaki, G.L., Gorin, A.J. and Iacomini, M. (2012) Chemical and biological properties of a highly branched $\beta$-glucan from edible mushroom Pleurotus sajor-caju. Carbohydr. Polym., 90(2): 814-819.

14. Villares, A., Mateo-Vivaracho, L. and Guillamón, E. (2012) Structural features and healthy properties of polysaccharides occurring in mushrooms. Agriculture, 2(4): 452-471.

15. Bagni, M., Romano, N., Finoia, M., Abelli, L., Scapigliati, G., Tiscar, P., Sarti, M. and Marino, G. (2005) Short and long-term effects of a dietary yeast $\beta$-glucan (Macrogard) and alginic acid (Ergosan) preparation on immune response in sea bass (Dicentrarchus labrax). Fish Shellfish Immunol., 18(4): 311-325.

16. Handayani, D., Meyer, B., Chen, J., Brown, S., Mitchell, T. and Huang, X.F. (2014) A high-dose shiitake mushroom increases hepatic accumulation of triacylglycerol in rats fed a high-fat diet: Underlying mechanism. Nutrients, 6(2): 650-662.

17. Domenico, J.D., Canova, R., Soveral, L.D.F., Nied, C.O., Costa, M.M., Frandoloso, R. and Kreutz, L.C. (2017) Immunomodulatory effects of dietary $\beta$-glucan in silver catfish (Rhamdia quelen). Pesq. Vet. Bras., 37(1): 73-78.

18. Sinha, A.K., Kumar, V., Makkar, H.P., De Boeck, G. and Becker, K. (2011) Non-starch polysaccharides and their role in fish nutrition a review. Food Chem., 127(4): 1409-1426.

19. Krogdahl, A., Hemre, G. and Mommsen, T. (2005) Carbohydrates in fish nutrition: Digestion and absorption in postlarval stages. Aquac. Nutr., 11(2): 103-122.

20. Bhakta, M. and Kumar, P. (2013) Mushroom polysaccharides as a potential prebiotic. Int. J. Health Sci. Res., 3(8): $77-84$.

21. Carbone, D. and Faggio, C. (2016) Importance of prebiotics in aquaculture as immunostimulants. Effects on immune system of Sparus aurata and Dicentrarchus labrax. Fish Shellfish Immunol., 54: 172-178.
22. Kühlwein, H., Merrifield, D.L., Rawling, M.D., Foey, A.D. and Davies, S.J. (2013) Effects of dietary $\beta-(1,3)$ $(1,6)$-D-glucan supplementation on growth performance, intestinal morphology and haemato-immunological profile of mirror carp (Cyprinus carpio L.). J. Anim. Physiol. Anim. Nutr., 98(2): 279-289.

23. Grzelak, A.K., Davis, D.J., Caraker, S.M., Crim, M.J., Spitsbergen, J.M. and Wiedmeyer, C.E. (2017) Stress leukogram induced by acute and chronic stress in zebrafish (Danio rerio). Comp. Med., 67(4): 263-269.

24. Havixbeck, J.J. and Barreda, D.R. (2015) Neutrophil development, migration, and function in teleost fish. Biology, 4(4): 715-734.

25. Marwick, J.A., Mills, R., Kay, O., Michail, K., Stephen, J., Rossi, A.G., Dransfield, I. and Hirani, N. (2018) Neutrophils induce macrophage anti-inflammatory reprogramming by suppressing NF-kB activation. Cell Death Dis., 9(6): 665.

26. Charlie-Silva, I., Klein, A., Gomes, J.M.M., Prado, E.J.R., Moraes, A.C., Eto, S.F., Fernandes, D.C., Fagliari, J.J., Junior J.D.C., Lima, C., Lopes-Ferreira, M., Conceição, K., Manrique, W.G. and Belo, M.A.A. (2019) Acute-phase proteins during inflammatory reaction by bacterial infection: Fish-model. Sci. Rep., 9(1): 4776.

27. El Kebir, D. and Filep, J.G. (2010) Role of neutrophil apoptosis in the resolution of inflammation. Scientific World Journal., 10: 1731-1748.

28. Svobodova, Z., Kroupova, H., Modra, H., Flajshans, M., Randak, T., Savina, L.V. and Gela, D. (2008) Haematological profile of common carp spawners of various breeds. J. Appl. Ichthyol., 24(1): 55-59.

29. Safari, O. and Sarkheil, M. (2018) Dietary administration of eryngii mushroom (Pleurotus eryngii) powder on haemato-immunological responses, bactericidal activity of skin mucus and growth performance of koi carp fingerlings (Cyprinus carpio, Koi). Fish Shellfish Immun., 80: 505-513.

30. Minato, K., Laan, L.C., Die, I.V. and Mizuno, M. (2019) Pleurotus citrinopileatus polysaccharide stimulates anti-inflammatory properties during monocyte-to-macrophage differentiation. Int. J. Biol. Macromol., 122: 705-712.

31. Garcia-Valtanen, P., Guzman-Genuino, R.M., Williams, D.L., Hayball, J.D. and Diener, K.R. (2017) Evaluation of trained immunity by $\beta-1,3$ (d)-glucan on murine monocytes in vitro and duration of response in vivo. Immunol. Cell Biol., 95(7): 601-610.

32. Wolke, R.E. (1992) Piscine macrophage aggregates: A review. Annu. Rev. Fish Dis., 2: 91-108.

33. Reyes-Becerril, M., Guardiola, F., Rojas, M., AscencioValle, F. and Esteban, M.Á. (2013) Dietary administration of microalgae Navicula sp. affects immune status and gene expression of gilthead seabream (Sparus aurata). Fish Shellfish Immunol., 35(3): 883-889.

34. Granum, E. and Myklestad, S.M. (2002) A simple combined method for determination of $\beta$-1,3-glucan and cell wall polysaccharides in diatoms. Hydrobiologia, 477: 155-161.

35. Steinel, N.C. and Bolnick, D.I. (2017) Melanomacrophage centers as a histological indicator of immune function in fish and other poikilotherms. Front. Immunol., 8: 827.

36. Yadav, M. and Schorey, J.S. (2006) The beta-glucan receptor dectin-1 functions together with TLR2 to mediate macrophage activation by mycobacteria. Blood, 108(9): 3168-3175. 